\section{The Impact of Severity and Time of Tipping and Hedging on Performance of Primocane-fruiting Blackberry in a Tunnel}

\author{
Bernadine C. Strik ${ }^{1,3}$ and Gil Buller ${ }^{2}$
}

AdDITIONAL INDEX WORDs. Rubus, 'Prime-Jan'®, summer pruning, fruit size, primocane management, tunnel production

\begin{abstract}
SuMmARY. Summer pruning systems were compared for 'Prime-Jan' ${ }^{\circledR}$ primocanefruiting blackberry ( $R u b u s$ subgenus $R u b u s)$ grown in a fully closed, plastic covered tunnel in Aurora, OR. Individual canes were soft-tipped (by removing $0.10 \mathrm{~m}$ ) or hard-tipped (removing $0.45 \mathrm{~m}$ ) to a $1-\mathrm{m}$ height on each of four dates in 2008 and 2009. On average, canes that were hard-tipped produced more branches and had more fruit/cane than soft-tipped canes. Canes that were tipped early (22-27 June) produced more fruit/cane than those tipped later (7-24 July). When canes were hard-tipped early in the season, the number of fruit/cane was increased threefold compared with soft-tipping canes early. In contrast, when plots were hedged to $1-\mathrm{m}$ tall lightly ("soft" hedge removing $0.10 \mathrm{~m}$ ) on 22-27 June or more severely ("hard" hedge, removing $0.45 \mathrm{~m}$ ) on 29 June-2 July, using shears, there was no significant effect on yield/plot. The hard-hedge treatments may have performed better if they had been done earlier or at the same time as the soft-hedge treatments; this would only have been possible if canes had been cut back (hedged) to a shorter height than $1 \mathrm{~m}$. Hard hedging, done $\approx 1$ week later than soft hedging, delayed the fruiting season by 10-14 days. Fruit harvest continued until early to mid-November. Daily average air temperature in the closed tunnel was $2-7^{\circ} \mathrm{F}$ warmer than the outside and fruit were protected from autumn rainfall. Hard-tipping individual canes, by hand, or hedging primocanes mechanically early in the season shows promise in this crop for maximizing economic returns.
\end{abstract}

S oft-tipping (removal of $2-5 \mathrm{~cm})$ primocane-blackberry canes once (Drake and Clark, 2003; Strik et al., 2008 and 2012; Thompson et al., 2009) or double-tipping (main cane and branches; Thompson et al., 2009) has been shown to increase yield compared with untipped canes and has become standard industry practice (B.C. Strik, personal observation). Soft-tipped primocanes have a greater number of branches/cane and fruit/cane than untipped canes (Strik et al., 2008, 2012; Thompson et al., 2007), and yield/cane is highly correlated with the number of branches/cane (Strik et al., 2012). Drake and Clark (2003) found that tipping canes had no impact on

\footnotetext{
The authors appreciate research funding support provided by the Oregon Raspberry and Blackberry Commission and industry support from Haygrove Tunnels, Herefordshire, Ledbury, UK.

We appreciate the valuable assistance of Nicole Hampton and Ellen Thompson.

${ }^{1}$ Professor, Department of Horticulture, Oregon State University, 4017 ALS, Corvallis, OR 97331

${ }^{2}$ Senior Research Assistant, North Willamette Research and Extension Center, 15210 NE Miley Road, Aurora, OR 97002

${ }^{3}$ Corresponding author. E-mail: strikb@hort.oregonstate. edu.
}

harvest season, whereas Strik et al. (2012) reported that soft-tipping advanced the fruiting season by $\approx 1$ week compared with untipped canes.

Date of tipping during the growing season has affected yield and fruiting season of primocane-fruiting blackberry (Drake and Clark, 2003) and raspberry (Rubusidaeus) (Jordan and Ince, 1986; Richter et al., 1989). However, the late tipping treatments studied by Drake and Clark (2003) were after the canes had already formed flower buds. Tipping at this stage of development has been observed to reduce yield (B.C. Strik, personal observation).
Primocane-fruiting blackberries produce new primocanes (flushes) from buds on the roots or crown throughout the growing season. In a temperate climate, the later flushes of growth have been shown to be unproductive (Strik et al., 2012). Growers presently go through a field on several occasions during the growing season to soft-tip primocanes, by hand, to the desired height. The impact of tipping date on reproductive potential is not known in this crop. While the traditional soft-tipping method has been shown to increase yield compared with untipped canes, hard-tipping would cut the cane back to older growth and potentially more mature buds. It would likely be easier to mechanize hard hedging in commercial production systems.

Our hypotheses were 1) hardtipping canes, by cutting back to older growth and more mature buds, would increase the number of branches and potential yield compared with softtipping; 2) tipping early in the season would increase yield compared with tipping later in the season; and 3 ) mechanical hedging systems can be developed to provide an economic alternative to hand-tipping of primocanes.

\section{Materials and methods}

The research planting was established on 6 May 2005 at the North Willamette Research and Extension Center in Aurora, OR [lat. $45^{\circ} 17^{\prime} \mathrm{N}$, long. $122^{\circ} 45^{\prime} \mathrm{W}$, U.S. Department of Agriculture hardiness zone 8, elevation $150 \mathrm{ft}$, average last freeze date 17 Apr., average first freeze date 25 Oct. (U.S. Department of the Interior, 2012)].

The site was a Willamette soil type (fine-silty, mixed mesic Pachic Ultic Argixerolls) with pH 5.6. In the fall before planting, $2.3 \mathrm{t} /$ acre of

\begin{tabular}{llll}
\hline $\begin{array}{l}\text { Units } \\
\text { To convert U.S. to SI, } \\
\text { multiply by }\end{array}$ & U.S. unit & SI unit & $\begin{array}{l}\text { To convert SI to U.S., } \\
\text { multiply by }\end{array}$ \\
\hline 0.3048 & $\mathrm{ft}$ & $\mathrm{m}$ & 3.2808 \\
3.7854 & gal & $\mathrm{L}$ & 0.2642 \\
2.54 & inch(es) & $\mathrm{cm}$ & 0.3937 \\
25.4 & inch(es) & $\mathrm{mm}$ & 0.0394 \\
0.4536 & $\mathrm{lb}$ & $\mathrm{kg}$ & 2.2046 \\
1.1209 & $\mathrm{lb} / \mathrm{acre}$ & $\mathrm{kg} \cdot \mathrm{ha}^{-1}$ & 0.8922 \\
0.0254 & mil & $\mathrm{mm}$ & 39.3701 \\
28.3495 & $\mathrm{oz}$ & $\mathrm{g}$ & 0.0353 \\
2.2417 & ton/acre & $\mathrm{Mg} \cdot \mathrm{ha}^{-1}$ & 0.4461 \\
0.9144 & yard(s) & $\mathrm{m}$ & 1.0936 \\
$\left({ }^{\circ} \mathrm{F}-32\right) \div 1.8$ & ${ }^{\circ} \mathrm{F}$ & ${ }^{\circ} \mathrm{C}$ & $\left(1.8 \times{ }^{\circ} \mathrm{C}\right)+32$
\end{tabular}


dolomite lime $\left[\mathrm{CaMg}\left(\mathrm{CO}_{3}\right)_{2}\right], 43$ $\mathrm{lb} /$ acre of potassium, and $2.4 \mathrm{lb} /$ acre of boron were incorporated into the soil. The 2-gal potted 'Prime-Jan' ${ }^{\circledR}$ plants were established in an uncovered high tunnel $(200 \times 27 \mathrm{ft}$; Haygrove Tunnels, Ledbury, UK). Plants were spaced $2 \mathrm{ft}$ in the row with $10 \mathrm{ft}$ between rows.

The planting was drip irrigated (1 gal/h with emitters at 2 - $\mathrm{ft}$ spacing) as required, typically $30 \mathrm{~min}$ twice daily (1 gal/d), from June to Sept. 2008 and 2009, and 15 min every other day $(0.125 \mathrm{gal} / \mathrm{d})$ in Oct. and Nov. 2008 and 2009. Plastic film (6mil, Luminance THB; Visqueen Building Products, Heanor, UK) was placed over the tunnel in early September, $\approx 2-3$ weeks before fruit harvest, and the tunnel ends were sealed (with plastic) in early October of each year. The plastic was left on the tunnel for the duration of fruit harvest. The tunnel was vented (sides and doors) when necessary to protect against excessive heat and wind gusts. No supplemental heat was provided in the tunnel.

In late winter (about late February) of each year, plants from all treatments were pruned to the ground height. The planting was thus only grown for a primocane crop. Plots were fertilized with $50 \mathrm{lb} /$ acre nitrogen, $13.8 \mathrm{lb} /$ acre phosphorus, and $48.9 \mathrm{lb} /$ acre potassium each spring, as a split application in April and May. Weeds were controlled by use of preemergent herbicides and mechanical methods as required. The hedgerow width of each plot was maintained at $1.5 \mathrm{ft}$ by cultivation. Canes were trained between double sets of trellis wires located at 1 - and 5 -ft height, but were not tied to the wires. The following experiments were conducted in the mature planting in 2008 and 2009.

EXPT. 1. Individual primocanes were soft-tipped $(0.10 \mathrm{~m}$ of cane tip removed when the cane was $1.1-\mathrm{m}$ tall) or hard-tipped $(0.45 \mathrm{~m}$ of cane tip removed when the cane was $1.45-\mathrm{m}$ tall) on each of four dates in 2008 and 2009. Canes were randomly selected to meet the height criteria with eight replicates per treatment; canes that had any evidence of flower buds at their tip were not selected for the study; tipping after inflorescences have appeared has been shown to reduce yield and berry weight (Drake and Clark, 2003; B.C. Strik, personal observation). Weeks were assigned to each tipping date to allow for comparison of similar dates among years (Table 1). Canes were marked with flagging to designate treatment, but otherwise were part of the mature hedgerow and managed according to standard commercial practice.

In late October, each flagged treatment cane was cut at ground level and removed from the planting. Data were recorded on number of branches, total branch length, total number of fruiting sites per cane (remnant pedicels of floral axes were counted where fruit excision was evident), and cane diameter below the tipping site (2009 only). The average length and fruit number per branch were calculated.

EXPт. 2. Plots were mechanically hedged lightly ("soft" hedge) on 27 June 2008 and 22 June 2009 or more severely ("hard" hedge) on 2 July 2008 and 29 June 2009. Hedging was done using hand shears. The dates for soft and hard hedging were selected when the majority of primocanes in the plots were $\approx 1.1$ - and $1.45-\mathrm{m}$ tall, respectively. The primocanes were hedged to a height of $1 \mathrm{~m}$ for each treatment. The five-plant plots were 10 -ft long with 5 - $\mathrm{ft}$ separating plots. There were four replicates of each treatment arranged in a completely random design.

Plots were harvested by hand (every $7 \mathrm{~d}$ ) with total yield per harvest date and average berry weight $(25$ berries per harvest date) measured. Fruit harvest was from 29 Sept. to 17 Nov. 2008 and 18 Sept. to 5 Nov. 2009. A subsample of three fruiting primocanes/plot was collected and data recorded on number of branches, total branch length, total number of fruiting sites per cane, and cane diameter below the tipping site (2009 only). The average length and fruit number per branch were calculated.

Air temperature and relative humidity were recorded in the tunnel, once closed, using data loggers (HOBO Pro Series; Onset Computer Corporation, Bourne, MA) and from a weather station located $\approx 300$ yards from the tunnel (U.S. Department of the Interior, 2012). Data points for temperature and relative humidity were logged once per hour and daily averages calculated. Tunnel temperature and humidity data were only available
Table 1. Dates on which individual canes of 'Prime-Jan' ${ }^{\circledR}$ blackberry plants were soft- or hard-tipped in 2008 and 2009 (Expt. 1) at Oregon State University's North Willamette Research and Extension Center, Aurora, OR.

\begin{tabular}{lcc}
\hline Week no. & $\mathbf{2 0 0 8}$ & $\mathbf{2 0 0 9}$ \\
\hline 1 & - & 22 June \\
2 & 27 June & 29 June \\
3 & 2 July & 7 July \\
4 & 9 July & 14 July \\
5 & - & - \\
6 & 24 July & - \\
\hline
\end{tabular}

from 9 Oct. to 21 Oct. 2008 and 20 Oct. to 9 Nov. 2009.

Analysis of variance was performed for year, week, and treatment effects for each experiment using PROC MIXED in SAS (version 9.1; SAS Institute, Cary, NC). Means were separated at the $P=0.05$ level using Duncan's new multiple range test. In Expt. 2, yield was correlated with various components using PROC CORR in SAS.

\section{Results and discussion}

The average air temperature in the closed tunnel was 7 and $2{ }^{\circ} \mathrm{F}$ warmer than the recorded outside temperature over the measurement period in 2008 and 2009 , respectively (Fig. 1; U.S. Department of the Interior, 2012). The relative humidity in the tunnel ranged from $\approx 60 \%$ to $97 \%$ in both years (data not shown). The tunnel cover protected fruit from rain during harvest; a total of 5.90 inches of rain fell during the harvest season in 2008 and 4.02 inches in 2009 when the tunnel plastic protected the experimental plants (Fig. 2). The number of days with measurable precipitation was similar among the years with $24 \mathrm{~d}$ in 2008 and $22 \mathrm{~d}$ in 2009 (Fig. 2).

ExPT. 1. All cane variables were significantly affected by tipping severity, week of tipping, and year (except for branch number). While there was no interaction of year $x$ severity or year $x$ week of tipping, there was a tipping severity $\times$ week interaction for total and average branch length, and total fruit per cane (Table 2).

Canes produced a similar number of branches after tipping in both years, but branches produced in 2008 were longer and produced more fruit 


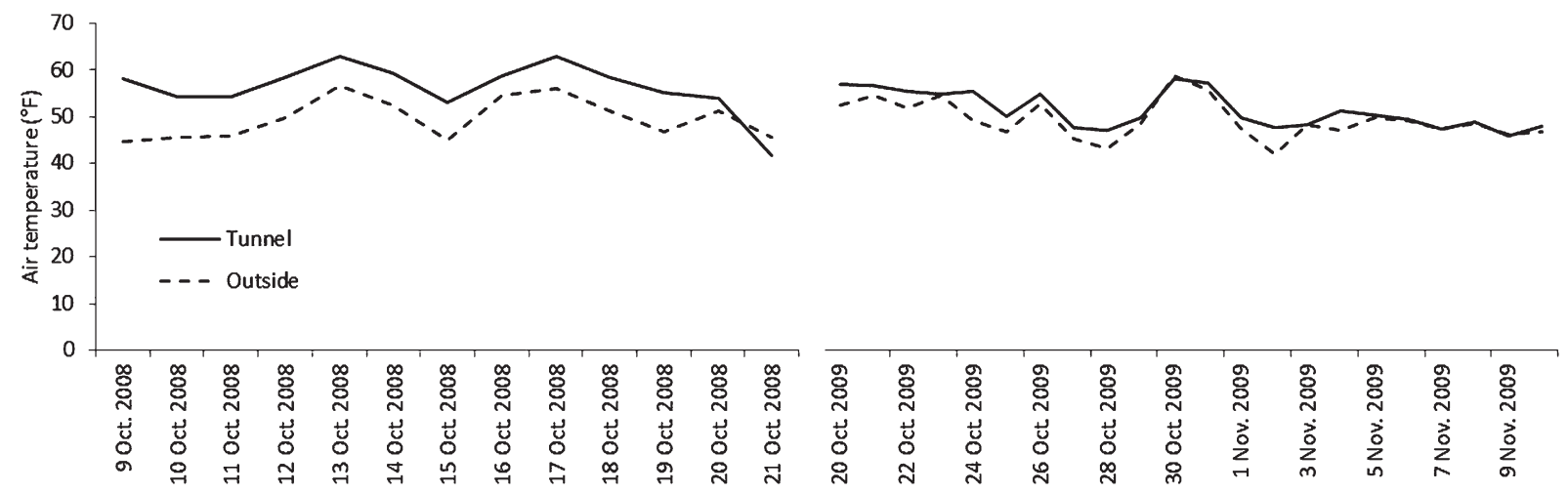

Fig. 1. Average daily air temperature (hourly, $24 \mathrm{~h}$ ) in a closed, unheated tunnel and outside the tunnel from 9 Oct. to 21 Oct. 2008 and 20 Oct. to 9 Nov. 2009 at Oregon State University's North Willamette Research and Extension Center in Aurora, OR; $\left({ }^{\circ} \mathrm{F}-32\right) \div 1.8={ }^{\circ} \mathrm{C}$.

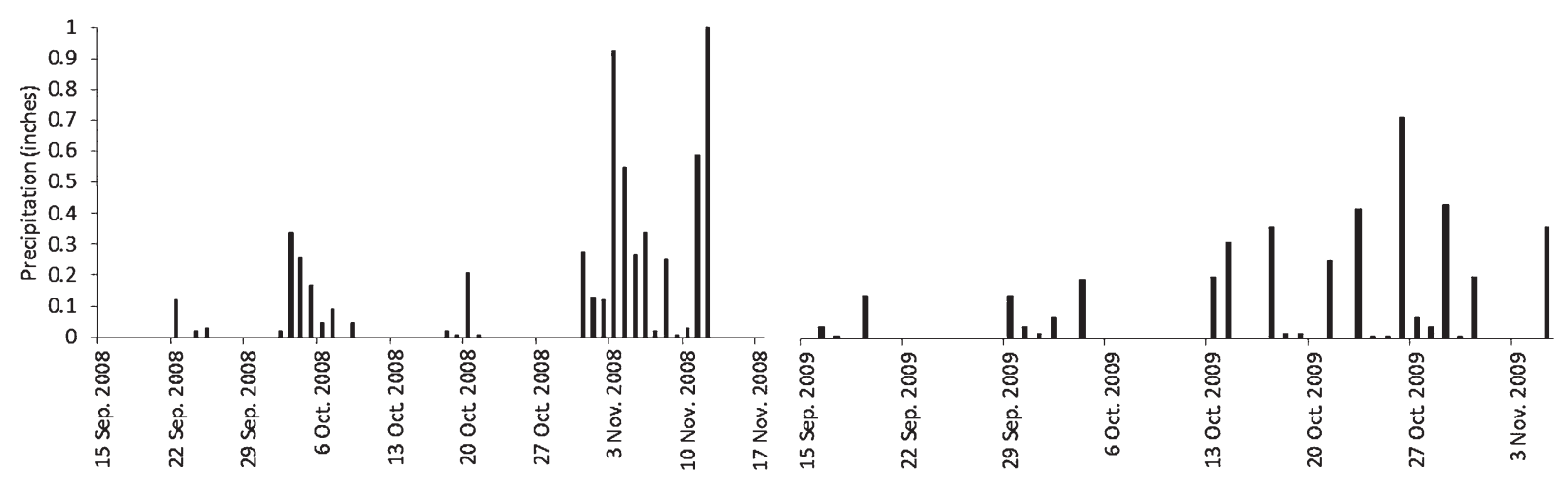

Fig. 2. Total daily precipitation outside the tunnel from 15 Sept. to the end of harvest on 17 Nov. 2008 and 5 Nov. 2009 at Oregon State University's North Willamette Research and Extension Center in Aurora, OR; 1 inch $=2.54 \mathrm{~cm}$.

(Table 2). Since the plantings were managed similarly among years, it is possible that the warmer temperatures inside the tunnel in $2008 \mathrm{com}$ pared with 2009 (average of $5{ }^{\circ} \mathrm{F}$ higher) promoted better growth and fruit development (Fig. 1). Outside average air temperatures were also warmer in 2008 than in 2009 during the fruit harvest period (data not shown; U.S. Department of the Interior, 2012).

On average, canes that were hardtipped produced more branches that were longer and had more fruit than canes that were soft-tipped. Tipping in this study produced fewer branches per cane than soft-tipped canes of 'Prime-Jan' ${ }^{\circledR}$ in an open field-grown study at this same location in 200405 (Strik et al., 2012). High planting density, as is often observed in tunnels (B.C. Strik, personal observation), and reduced light may have decreased branch production as has been noted in other studies on blackberry (Cortell and Strik, 1997; Strik et al., 2012;
Swartz et al., 1984). The branches on tipped canes were found near the cut tip of the cane as has been reported previously (Strik et al., 2012).

There was no effect of week of tipping on the number of branches produced (Table 2 ). When canes were soft-tipped, there was relatively little effect of week of tipping on average branch length, except soft-tipping on week 4 (early July) that reduced branch length and fruit/cane relative to earlier or later tipping. The greatest number of fruit/cane was produced when primocanes were tipped early (22-27 June) and especially when they were hard-tipped, which increased fruit/ cane threefold compared with softtipping. When canes were hard-tipped, average branch length and fruit/cane generally decreased as tipping was done later in the season (Table 2). Cane diameter at the tipping site averaged 4 and $9 \mathrm{~mm}$ for soft- and hard-tipped canes, respectively and decreased as canes were tipped later in the season (data not shown). Hard-tipping canes, and thus cutting back to older growth, may have improved bud maturity near the tipping site. Since canes had to be selected that were of the correct height for tipping, it is likely that canes that were tipped later in the season were from later flushes of growth-these may be less productive in our temperate climate (Strik et al., 2012). Oliveira et al. (1998) found that summer tipping primocane-fruiting raspberry later in the season reduced yield.

The highest number of fruit/ branch was found in the early tipped treatments. As canes were tipped later, fruit/branch dropped below previously reported averages of 16-23 (Strik et al., 2012). Within tipping severity and year, total fruit number/cane was positively correlated with the number of branches /cane $(r=0.842, P<$ $0.0001, n=32)$ (data not shown).

ExPT. 2. Yield per plot was higher in 2008 than 2009 (Table 3 and Fig. 3 ), perhaps due to higher average air temperatures, as we mentioned previously. Similar to our results for individual 
cane treatments in Expt. I (Table 2), there were more branches /cane, longer branches, and more fruit/cane in 2008 than in 2009 in the hedged plots.

Our results from performing a hard-tip by hedging were in contrast to the individual cane results because hard hedging did not increase the number of branches/cane, branch length, or fruit/cane compared with soft-tip hedging. There was no significant effect of severity of hedging on total yield/plot, but there was a trend for soft-tip hedging to increase yield (Fig. 3 and Table 3 ). For the

Table 2. The impact of soft- and hard-tipping during the season on cane architecture of 'Prime-Jan' ${ }^{\circledR}$ blackberry plants in 2008 and 2009 at Oregon State University's North Willamette Research and Extension Center in Aurora, OR.

\begin{tabular}{lcccc}
\hline Treatment & $\begin{array}{c}\text { Branches } \\
(\text { no. })\end{array}$ & $\begin{array}{c}\text { Avg branch } \\
\text { length }(\mathbf{c m})^{\mathrm{z}}\end{array}$ & $\begin{array}{c}\text { Total fruit } \\
(\text { no. } / \text { cane })\end{array}$ & $\begin{array}{c}\text { Avg fruit } \\
\text { (no./branch) }\end{array}$ \\
\hline $\begin{array}{l}\text { Year } \\
2008\end{array}$ & $3.4 \mathrm{a}$ & $40 \mathrm{a}$ & $58 \mathrm{a}$ & $17.1 \mathrm{a}$ \\
$\quad 2009$ & $3.0 \mathrm{a}$ & $25 \mathrm{~b}$ & $38 \mathrm{~b}$ & $11.0 \mathrm{~b}$ \\
$\begin{array}{l}\text { Tipping severity } \\
\quad \text { Soft }\end{array}$ & $2.2 \mathrm{~b}$ & $24 \mathrm{~b}$ & $30 \mathrm{~b}$ & $12.4 \mathrm{~b}$ \\
$\quad$ Hard & $4.2 \mathrm{a}$ & $40 \mathrm{a}$ & $66 \mathrm{a}$ & $15.7 \mathrm{a}$
\end{tabular}

Week of tipping ${ }^{\mathrm{x}}$

\begin{tabular}{lcccccc} 
& & Soft & Hard & Soft & Hard & \\
1 & 3.4 & $25 \mathrm{~b}$ & $63 \mathrm{a}$ & $43 \mathrm{a}$ & $128 \mathrm{a}$ & $15.5 \mathrm{ab}$ \\
2 & 3.6 & $25 \mathrm{~b}$ & $46 \mathrm{~b}$ & $32 \mathrm{~b}$ & $79 \mathrm{~b}$ & $18.1 \mathrm{a}$ \\
3 & 3.3 & $23 \mathrm{~b}$ & $34 \mathrm{c}$ & $23 \mathrm{c}$ & $47 \mathrm{c}$ & $13.1 \mathrm{~b}$ \\
4 & 2.7 & $12 \mathrm{c}$ & $22 \mathrm{~d}$ & $10 \mathrm{~d}$ & $34 \mathrm{~d}$ & $11.5 \mathrm{~b}$ \\
5 & - & - & - & - & - & - \\
6 & 3.3 & $33 \mathrm{a}$ & $30 \mathrm{c}$ & $29 \mathrm{~b}$ & $37 \mathrm{~d}$ & $11.2 \mathrm{~b}$ \\
Significancew $_{\text {Year }}$ & & & & & & \\
Severity & $\mathrm{NS}$ & $<0.0001$ & $<0.0001$ & $<0.0001$ \\
Week & $<0001$ & $<0.0001$ & $<0.0001$ & 0.007 \\
Severity $\times$ week & $\mathrm{NS}$ & $<0.0001$ & $<0.0001$ & $<0.0001$ \\
\hline
\end{tabular}

${ }^{\mathrm{z}} 1 \mathrm{~cm}=0.3937$ inch.

"Canes "soft"-tipped had $0.1 \mathrm{~m}$ of cane tip removed when cane was 1.1 -m tall; "hard"-tipped canes had $0.45 \mathrm{~m}$ of cane tip removed when cane was $1.45-\mathrm{m}$ tall; $1 \mathrm{~m}=3.2808 \mathrm{ft}$. Main effect $(n=64)$.

${ }^{x}$ Week of tipping from 22 June to 24 July (see Table 1). Averaged over year. Interaction with tipping severity shown when significant.

${ }^{{ }^{w}}$ S $=$ nonsignificant by analysis of variance at $P>0.05$. Probability values shown for significant effects; nonsignificant interactions of year $\times$ severity, of year $\times$ week, and year $\times$ severity $\times$ week are not shown. Means followed by the same letter within treatment are not significantly different at $P>0.05$.

hedging treatments, we had to wait until a majority of the canes were 1.10and $1.45-\mathrm{m}$ tall for the soft and hard hedge, respectively. Soft hedging was thus done $\approx 1$ week earlier in the season (22-27 June) than hard hedging (29 June or 2 July). In Expt. 1, we found that earlier tipping improved the number of branches/cane and fruit/cane. The hard-hedging treatments may have performed better if they had been done earlier or at the same time as the soft-hedging treatments; this would only have been possible if canes had been cut back (hedged) to a shorter height than $1 \mathrm{~m}$ on week 1. Thompson et al. (2009) found that canes tipped as short at $0.5 \mathrm{~m}$ produced high yield. It is also possible that when plots were hedged, some canes were tipped that had already produced flower buds; this would have led to a reduction in yield/plot (Drake and Clark, 2003; B.C. Strik, personal observation). Waiting until a majority of canes were long enough to do a hard hedge would increase the probability that some canes had become reproductive.

Hard hedging delayed the fruiting season (date on which $1 \mathrm{~kg} /$ plot had been harvested as per Strik et al., 2012) by 10-14 d (Fig. 3). "Hardtipping" (removal of $0.3 \mathrm{~m}$ ) 'Heritage' primocane-fruiting red raspberry to $1 \mathrm{~m}$ delayed fruiting (Jordan and Ince, 1986; Richter et al., 1989). While the fruiting season in our study started later than previously reported at this site in 2004-05 (Strik et al., 2012), fruit harvest continued until

Table 3. The impact of soft and hard hedging on yield/plot and cane architecture of 'Prime-Jan' ${ }^{\circledR}$ blackberry in 2008 and 2009 at Oregon State University's North Willamette Research and Extension Center in Aurora, OR.

\begin{tabular}{|c|c|c|c|c|c|c|}
\hline Treatment & $\begin{array}{c}\text { Yield } \\
(\mathrm{kg} / \text { plot })^{\mathrm{z}}\end{array}$ & $\begin{array}{l}\text { Berry wt } \\
(\mathrm{g})^{\mathrm{z}}\end{array}$ & $\begin{array}{c}\text { Branches } \\
\text { (no.) }\end{array}$ & $\begin{array}{c}\text { Avg } \\
\text { branch } \\
\text { length }(\mathrm{cm})^{\mathrm{z}}\end{array}$ & $\begin{array}{l}\text { Total fruit } \\
\text { (no./cane) }\end{array}$ & $\begin{array}{c}\text { Avg fruit } \\
\text { (no./branch) }\end{array}$ \\
\hline 2008 & $4.9 \mathrm{a}$ & $6.7 \mathrm{a}$ & $4.7 \mathrm{a}$ & $52 \mathrm{a}$ & $81 \mathrm{a}$ & $17.9 \mathrm{a}$ \\
\hline 2009 & $3.4 \mathrm{~b}$ & $6.0 \mathrm{~b}$ & $3.9 \mathrm{~b}$ & $41 \mathrm{~b}$ & $64 a$ & $17.1 \mathrm{a}$ \\
\hline \multicolumn{7}{|l|}{ Tipping severity ${ }^{\mathrm{y}}$} \\
\hline \multicolumn{7}{|l|}{ Significance $^{\mathrm{x}}$} \\
\hline Year & 0.0491 & 0.0133 & 0.0133 & 0.0089 & NS & NS \\
\hline Severity & NS & 0.0499 & 0.0224 & NS & NS & NS \\
\hline Year $\times$ severity & NS & NS & NS & NS & NS & NS \\
\hline
\end{tabular}

${ }^{2} \mathrm{l} \mathrm{kg}=2.2046 \mathrm{lb}, \mathrm{l} \mathrm{g}=0.0353 \mathrm{oz}, \mathrm{l} \mathrm{cm}=0.3937$ inch.

"Canes "soft"-tipped were mechanically hedged when the majority of the primocanes/plot were 1.1 -m tall ( $0.1 \mathrm{~m}$ of cane tip was removed) on 27 June 2008 and 22 June 2009 ; $1 \mathrm{~m}=3.2808 \mathrm{ft}$. "Hard"-tipped plots were hedged on 2 July 2008 and 29 June 2009 when the majority of primocanes were 1.45 - $\mathrm{m}$ tall $(0.45 \mathrm{~m}$ of cane tip removed). Main effect $(n=8)$.

${ }^{\mathrm{x}} \mathrm{NS}=$ nonsignificant by analysis of variance at $P>0.05$. Probability values shown for significant effects. Means followed by the same letter within treatment are not significantly different at $P>0.05$. 

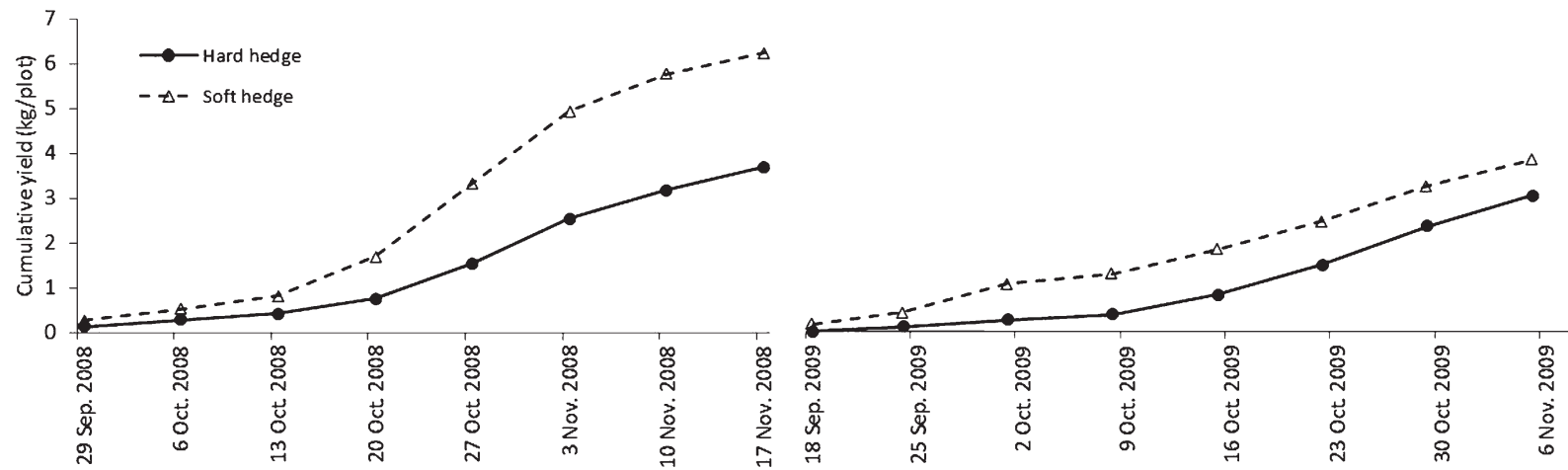

Fig. 3. Cumulative yield of 'Prime-Jan' ${ }^{\circledR}$ blackberry plants mechanically hedged to $1-\mathrm{m}$ tall by removing $0.10 \mathrm{~m}$ ("soft") or $0.45 \mathrm{~m}$ ("hard") in 2008 and 2009 when grown in a closed tunnel $(n=4)$ at Oregon State University's North Willamette Research and Extension Center in Aurora, OR; $1 \mathrm{~m}=3.2808 \mathrm{ft}, 1 \mathrm{~kg}=2.2046 \mathrm{lb}$.

early to mid-November in the closed tunnel. Our harvest dates and yield were similar to those reported by Thompson et al. (2009) for 'Prime$\mathrm{Jan}^{\circledR}$ in $2006-07$ grown in a tunnel with ends open. Closing the tunnel, without providing any supplemental heat, may not have offered much of an advantage in our climate.

\section{Conclusions}

Experiments with individual canes showed that hard-tipping improved the reproductive performance of primocane-fruiting blackberry compared with soft-tipping. This supported our hypothesis that tipping to older growth and more mature buds improves branching and yield. Tipping date affected fruiting potential even when canes were vegetative at tipping; tipping early was important to maximize branching yield potential. We confirmed that branch number per cane is highly correlated with yield per cane.

While hedging shows potential for reducing labor costs of hand-tipping primocane-fruiting blackberry, the standard industry practice, growers must use caution when hedging to ensure that there are not too many canes in the row that have already formed a flower bud and to hedge as early as possible. Performing a hard hedge early in the season by cutting canes back to a shorter height than $1 \mathrm{~m}$ shows promise in this crop for maximizing economic returns.

\section{Literature cited}

Cortell, J.M. and B.C. Strik. 1997. Effect of floricane number in 'Marion' trailing blackberry. II. Yield components and dry mass partitioning. J. Amer. Soc. Hort. Sci. 122:611-615.

Drake, C.A. and J.R. Clark. 2003. Effects of pruning and cropping on field-grown primocane-fruiting blackberries. HortScience 38:260-262.

Jordan, D. and J. Ince. 1986. Primocane tipping to programme production in fall (autumn) cropping raspberries. HortScience 21:775, (abstr.).

Oliveira, P.B., C.M. Oliveira, P.V Machado, L. Lopes-da-Fonseca, and A.A. Monteiro. 1998. Improving offseason production of primocane-fruiting red raspberry by altering summer pruning intensity. HortScience 33:3133.

Richter, R., M. Kaps, and M. Odneal. 1989. Approaches to problems with the harvest season of 'Heritage' red raspberry in Missouri or isn't a fall-bearer supposed to bear in fall? Proc. 1989 Missouri Small Fruit Conf. 26-38.
Strik, B.C., J.R. Clark, C.E. Finn, and G. Buller. 2008. Management of primocane-fruiting blackberry to maximize yield and extend the fruiting season. Acta Hort. 777:423-428.

Strik, B.C., J.R. Clark, C.E. Finn, and G. Buller. 2012. Management of primocanefruiting blackberry-Impacts on yield, fruiting season, and cane architecture. HortScience 47:593-598.

Swartz, H.J., S.E. Gray, L.W. Douglass, E. Durner, C.S. Walsh, and G.J. Galletta. 1984. The effect of a divided canopy trellis design on thornless blackberry. HortScience 19:533-535.

Thompson, E., B.C. Strik, J.R. Clark, and C.E. Finn. 2007. Flowering and fruiting patterns of primocane-fruiting blackberries. HortScience 42:1174-1176.

Thompson, E., B.C. Strik, C.E. Finn, Y. Zhao, and J.R. Clark. 2009. High tunnel vs. open field: Management of primocanefruiting blackberry using pruning and tipping to increase yield and extend the fruiting season. HortScience 44:15811587.

U.S. Department of the Interior. 2012 . U.S. Department of the Interior, Bureau of Reclamation, AgriMet, Boise, ID. 2 Feb. 2012. <www.usbr.gov/pn/ agrimet/agrimetmap/araoda.html>. 